\title{
PEDOLOGICAL STUDIES ON SOME SOILS WEST IDFU ASWAN EGYPT BY USING REMOTE SENSING DATA
}

\author{
Wahdan,M.E.M; S.S..ELsayd; G.F.O EL Sheikh and F, S.A.Salama
}

Soils, Water and Environment Research Institute Agricultural Research

Center, Giza, Egypt .

\begin{abstract}
The study aims at using satellite images and Geographical Information System (GIS) for physiographic digital soil mapping and capability assessment of the area western side of Idfu district, Aswan Governorate, Western Desert .The area lies between longitude $32^{\circ}$ $29^{-} 45^{\circ}$ and $32^{\circ} 47^{-} 1332^{-}$E and latitudes $24^{\circ} 22^{-} 38^{-}$and $25^{\circ} 8^{-} 36^{=} \mathrm{N}$ and occupies total area about 139000 feddans. To fulfill this objective Landsat ETM+ image and digital elevation model (DEM) of the studied area were used to define the physiographic units of the studied area. The physiographic units of the area under consideration could be grouped and described as young terraces, old terraces, Wadi, Outwash plain .The different landforms were represented by 9 soil profiles, the morphological description was carried out and 26 disturbed soil samples were collected for physical and chemical analysis. The obtained results revealed that the soils of the studied area are classified as follow:
\end{abstract}

A)-Soils of Old Terraces: Typic Torriorthents, sandy, mixed, hyperthermic.(Profile8).Gypsic Haplosalids coarse loamy, mixed hyperthermic. (profile9) B)-Soils of the Young terraces: a) Typic Torripsamments siliceaus, hyperthermic (profil,1)-b) Gypsic Haplosalides coarse loamy, mixed, hyperthermic(profile,2)-c). Typic Haplosalides, coarse loamy ,mixed ,hyperthermic. profiles 2 and3. C)-Soils of Wadis: Typic Torriorthents, sandy, mixed, hyperthermic (profiles 4 and 5 ) D)-Soils of Outwash Plains:. TypicTorriorthents, sandy, mixed, hyperthermic (profile,6) Typic Calcigypsids, coarse loamy, mixed, hyperthermic (profile,7).

Land capability classes was performed using Sys \& Verheye (1978) System, The studied soils could be categorized into two suitability classes (S3) marginally suitable and $(\mathrm{N})$ not suitable which are suffering from soil texture, soil profile depth, salinity and alkalinity and $\mathrm{CaCO}_{3}$ content as soil limitations. To correct the severity of these limitations further land improvement should be executed and in turn potential suitability surveyed as moderately suitable (S2), marginally suitable (S3) and not suitable (N) were recognized in the studied area. The severity can be corrected by application of organic and inorganic soil amendments and salt leaching

Key Words: Remote sensing, GIS, Soil Classification, Soils of west Idfu, Aswan..

Fayoum J. Agric. Res. \& Dev., Vol. 31, No.1, January, 2017 
Desert land represents the great majority of the total area of Egypt, while the cultivated land does not exceed $4 \%$ and it is concentrated mainly along the Nile Valley and Delta .Accordingly, desert development is inviolable , not only as a source of agricultural production but also as a newly created area to attract population away from the overcrowded areas. The Western Desert of Egypt represents the most promising soils from the agricultural point of view due to its suitable land sources and presence of the vital roads. Land evaluation plays an important role for suitable sustainable management. As for long term sustainable productivity, soil must have a good and right soil management .Depending on this, soil survey works became more important spontaneously (Ozsoy 2007).

\section{LOCATION}

The Western Desert of Egypt stretches westwards from the Nile Valley to the borders with Libya and south wards from the Mediterranean Sea to the borders with Sudan .It occupies an area of $680.000 \mathrm{~km}^{2}$ (About $68 \%$ of the total area of Egypt).the Studied area is located in the south eastern part of the Egyptian Western Desert .It is located west of Idfu district Aswan Governorate and bounded by latitudes $24^{\circ} 22^{-} 38^{=}$and $25^{\circ} 8^{-} 36^{=}$North and longitude $32^{\circ}$ $29^{-} 45^{=}$and $32^{\circ} 47^{-} 13.32^{\circ} \mathrm{E}$ with area about $580 \mathrm{~km}^{2}(139000$ feddans), Fig(1). The main road in the studied area is Assuit -Aswan western desert road which connects Assuit and Aswan governments.

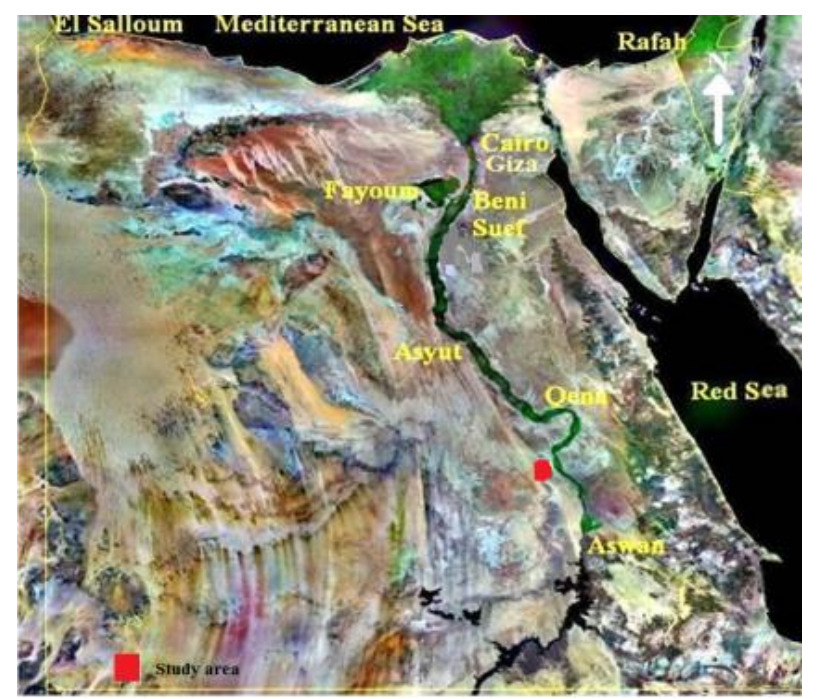

Fig (1). Location map of the area

Climate: The studied area is characterized by a hot and dry Summer with scanty winter rainfall and bright sunshine throughout the year .The average annual temperature is $22.7 \mathrm{C}^{\circ}$, and the average annual rainfall is $0.38 \mathrm{~mm}$. The

Fayoum J. Agric. Res. \& Dev., Vol. 31, No.1, January, 2017 
average relative humidity and evaporation rate are $23.3 \%$ and $7.76 \mathrm{~mm} /$ day ,respectively (Meteorological Authority, 2014).

Geology: The Nubian sandstones are the most important sediments rocks covering the area in addition to basement rocks which appear at some scattered sites .Generally, Quaternary sediments occupy most of the studied area .The Nubian sandstone is composed lithologically of a succession of sandstone beds, mostly fine to medium grained sometimes to coarse grained having different color gradations from white, yellow and brown. Its cementation ranged from friable to highly consolidate .The Quaternary sediments were found to a considerable extent, in the area ,topping the Nubian sandstone .They were represented by Aeolian sand and sand accumulations, sand dunes, and salt crusts. Aeolian sands were composed of loose, mostly fine, wind-blown sand, founded either in the form of thin sheets covering the flat tracts as accumulations filling the topographic lows, or sand dunes, (Thorweihe 1990).

Geomorphology: The studied area has two geomorphic units, the first one is almost flat, a complete group of river terraces in moderately elevation lowered Nile. The second unit is narrow flood plain adjacent to the west bank of the River Nile .The old river terraces are Pleo-pleistocene with elevation +100 to $+110 \mathrm{~m}$. above flood plain elevation .After them the Pleistocene terraces with elevation $+45 \mathrm{~m}$, appear. These terraces stretch on the left of the river bank forming a bar parallel to river. They are narrow in the north and south and extend somewhat in the middle. They are followed by terraces with $+30 \mathrm{~m}$ elevation .They belong to the upper Pleistocene and linked to the deposition period of silt (Abu Al-Ezz, 2000).

Water resources: The Nubian Sandston aquifer which covers an area exceeds 2 millions $\mathrm{km}^{2}$ is considered one of the biggest aquifers all over the world (Shehata,2003). The aquifer occupies the southern east portion of the Nubian sandstone region basin (EL-Kharga basin) with water depth varied between $21.25 \mathrm{~m}$-and59-85m-underground surface and with thickness ranged from $163.4 \mathrm{~m}$ to $658.2 \mathrm{~m}$.(EL-Osta, 2006 ). The aim of the current investigations is to identify the main physiographic units and their soil taxonomy as well as the natural constraints of the environmental factors, then the role of land evaluation system as a guide parameter for economical land use for the agriculture utilizations in some promising areas of the western side of Idfu district Aswan Governorate.

\section{Materials and Methods}

Digital Elevation Model (DEM) of the study area has been generated from the vector contour lines and with Landsat ETM+ image (path 175/row 39, taken 2005) in ERDAS Imagine 8.7 software to define the different landforms of the studied area using the geomorphic approach described by Zink and Valenzuala (1990) and Dobos et al (2002). The extracted data

Fayoum J. Agric. Res. \& Dev., Vol. 31, No.1, January, 2017 
Wahdan,M.E.M; et al.,

generate a preliminary geomorphologic map which was checked through field observation.

Field studies: A rapid reconnaissance survey was made throughout the investigated area in order to identify the major landforms and to gain an appreciation of the broad soil pattern and landscape characteristics . The primary mapping units were verified based on the pre-field interpretation and the information gained during the survey. Nine soil profiles were dug to fulfill requirements of checking the digital soil map in addition to 270 testing augers. The detailed morphological description of soil profiles was noted based on the basis outlined by FAO (2006). The summary of the studied soil profile description is shown in Table (1) .

Laboratory analysis: Physical analyses: Soil color (wet \& dry) was identified with the aid of Munssel Color Charts, (Soil Survey Staff, 2010). Particle size distribution was determined after USDA (2004). Electrical conductivity (ECe), soluble cations and anions, $\mathrm{pH}, \mathrm{CaCO}$, gypsum and organic matter content were determined according to USDA(2004). The soils were classified on the basis of the Key to Soil Taxonomy (USDA, 2014). Land Capability classification of Sys and Verheye (1978) was used to judge the soil grade for intensive agriculture. Land capability index were done using the rating tables suggested by FAO (1985), Sys and Verheye (1978) and Sys et al(1991) as common method for land evaluation according to the equation:

$\mathbf{C i}=\boldsymbol{t} \times \frac{w}{100} \times \frac{s 1}{100} \times \frac{s 2}{100} \times \frac{s 3}{100} \times \frac{s 4}{100} \times \frac{n}{100}$

$\mathrm{Ci}$ : Capability index (\%) . t :slop .W: Drainage condition. S1:textur . S2:Soil depth . S3:CaCO3\%. S4: Gypsum content, $\mathrm{n}$ :Salinity and alkalinity

Capability classes were arbitrary defined according to value of the index as follows:

\begin{tabular}{|c|c|c|}
\hline Capability class & Land index $(\mathbf{C i}) \%$ & Definition \\
\hline S1 & $>75$ & Soils are highly suitable \\
\hline S2 & $75-50$ & Soils are moderately suitable \\
\hline S3 & $50-25$ & Soils are marginally suitable \\
\hline N & $<25$ & Soils are not suitable \\
\hline
\end{tabular}

\section{3-RESULTS AND DISCUSSION}

\section{Geomorphology and soils:}

Based on Landsat ETM+ image, digital elevation model (DEM) and field work, check, the geomorphological units of the studied area has been identified(Fig 2).The studied area included different land forms and divided into four geomorphic units namely; Young Terraces, Old Terraces, Wadi and Out wash plain. The studied soils were represented by nine profiles and twenty nine samples of the soils in the different physiographic units. Soil

Fayoum J. Agric. Res. \& Dev., Vol. 31, No.1, January, 2017 
characteristics of the study area could be discussed based on data in Tables I, 2 and 3. Some of these characteristics could be summarized the following lines;

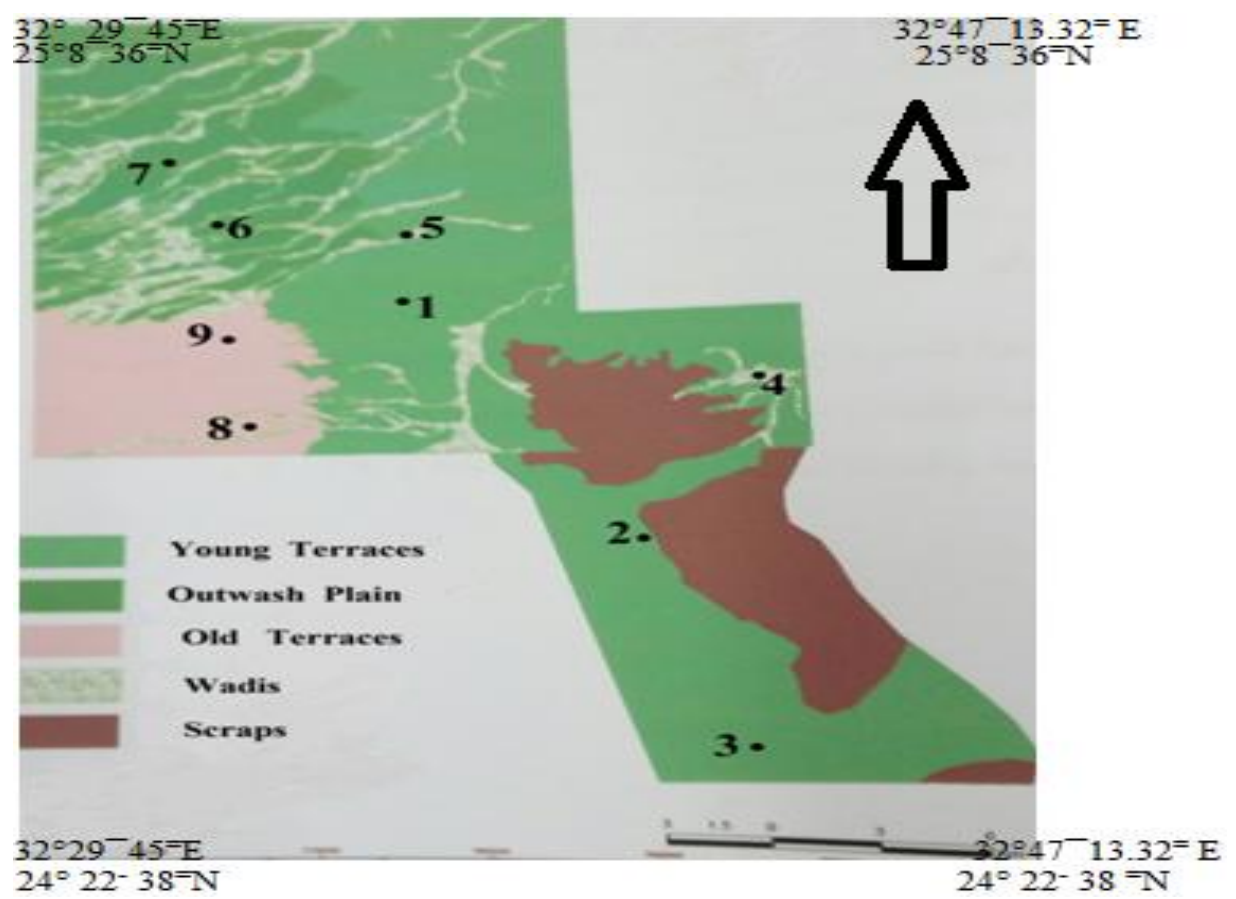

Fig (2) Physiographic unit of the study area .

A)-Soils of Old Terraces: The soils are represented by soil profiles 8 \&9. The soils are little developed in the Nubian sandstone area whereas they appear too extensive in the limestone country, may be due to the greater readability of the softer limestone with the result that more material was brought into the valley by lateral streams. These soils are of undulating to rolling relief and the soils are predominantly gravelly .The soils are almost very gravelly and thus have little value for the development of irrigated agriculture. Only in a part of the area of north of Idfu, the soils have loamy substrata of the former Pliocene gulf deposits of the Nile valley been found. Soils dry color varied between yellow (10YR7/6) and dark yellowish brown (10YR4/6), soil depth ranging from moderate to deep, soil texture varied from sand to sandy clay loam class, massive structure and gravel contents change between 10 and $35 \%$ (by volume).

Data of physical properties, which illustrated in Table(2), show that organic matter contents, did not exceeds $0.06 \%$ Total carbonate contents differ from 2.2 to $17.0 \%$ with an irregular distribution pattern with depth. Data in Tables (2 and 3) reveal the presence of a Calcic horizon in profile 9 (USDA, 2014) Gypsum contents ranged between 0.6 and $3.7 \%$ and their content was enough to the requirements of gypsic horizon in profiles 9. .Data

Fayoum J. Agric. Res. \& Dev., Vol. 31, No.1, January, 2017 
Wahdan,M.E.M; et al.,

in Table (3) show that soil reaction $(\mathrm{pH})$ was between 7.4 and 7.7 which reveals slightly alkaline reaction. The soils are non-saline to extremely saline where ECe values varied from 2.0 to $44 \mathrm{dSm}^{-1}$.Soluble cation were dominated with $\mathrm{Na}+$ followed by $\mathrm{Ca}^{2}+, \mathrm{Mg}^{2}+$ and $\mathrm{K}+$, while soluble anions were dominated by SO"4 and /or $\mathrm{Cl}^{-}$followed by $\mathrm{HCO}^{-}$3. The previous data and field observations showed that the soils under consideration are classify according USDA(2014) as follows :Typic Torriorthents ,sandy, mixed, hyperthermic.(Profile8).

Gypsic Haplosalids coarse loamy, mixed hyperthermic.in soils (profile9).

\section{B)-Soils of the Young terraces:}

The largest extent of young terraces soils is found west of the River and represented by soil profiles 1,2 and 3. This unit lies about 50 to $60 \mathrm{~m}$ above the Nile level and consists of complexes of gravel soils and somewhat loamy coarse sand soils, The older river terraces formation occure everywhere high soils adjacent to the present river terraces, only interrupted by some areas where the Nubian sandstone appeared as rock out crops . Between these outcrops the old river terraces deposits are again present, more or less eroded by gullies, formed in later erosion stages, which mostly drain to present river bed (FAO ,1963). The field observation , (Table ,1) reveal that topography of this unit varied between gently undulating to undulating, slope is nearly level , surface cover by common to many gravels of different sizes and haven't any native vegetation, soil depth is between moderately deep to deep where the depth of these soils is ranging between 70 and $120 \mathrm{~cm}$.. Soil dry color changes from light grey (10YR1/2 and dark yellowish brown (10YR4/6) .. These soils have different patterns of sedimentation showing sand to sandy loam textural classes. Different layers of the studied unit have massive structures. Gravel contents changed widely between 2.0 and $35 \%$ (by volume). Data in Table (2) reveal that organic matter contents changes from .04 to $0.13 \%$ and tend to decrease with depth, Total carbonate contents differ between 6.8 and $12.8 \%, \mathrm{t}$ Gypsum contents fluctuate from 0.5 and $5.9 \%$. Data in Table (1 and 2) showed that the soils have a gypsic horizons in profiles 2. Data of chemical analysis (Table3) reveal that soil $\mathrm{pH}$ values ranged between 7.0 and 8.3 i.e. neutral and moderately alkaline, Soil salinity (ECe) changes widely from 0.9 and 110.2 $\mathrm{dS} / \mathrm{m}^{-1}$, which are related to non-saline to very extremely saline (Salic horizon) Sodium adsorption ratio (SAR)is between 2.15 and 60.65 .The cationic composition of the soil saturation extract was dominated by $\mathrm{Na}+$ followed by $\mathrm{Ca}^{2}+, \mathrm{Mg}^{2}+$ while, $\mathrm{K}+$ was the least abundant soluble cations . The anionic composition was dominated by $\mathrm{Cl}^{-}$and $/ \mathrm{or} \mathrm{SO}^{-} 4$, while $\mathrm{HCO}^{-} 3$ was the least abundant soluble anions . The previous data of morphological features, physical and chemical analysis reveal that soils of this unit can be classifted according to USDA (2014) as follows :- a) Typic Torripsamments

Fayoum J. Agric. Res. \& Dev., Vol. 31, No.1, January, 2017 
PEDOLOGICAL STUDIES ON SOME SOILS WEST.

siliceaus, hyperthermic ( profil,1)- b) Gypsic Haplosalides coarse loamy, mixed, hyperthermic ( profile,2) -c) Typic Haplosalides ,coarse loamy ,mixed, hyperthermic profile, 3

Table (1) : Morphological description of the studied soil profiles.

\begin{tabular}{|c|c|c|c|c|c|c|c|c|c|c|c|c|c|c|c|c|c|}
\hline \multirow{2}{*}{ 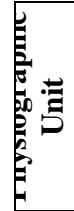 } & \multirow{2}{*}{ 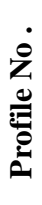 } & \multirow{2}{*}{ 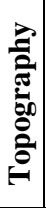 } & \multirow{2}{*}{$\frac{\check{a}}{\sigma}$} & \multirow{2}{*}{ 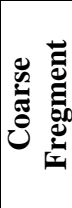 } & \multirow{2}{*}{ 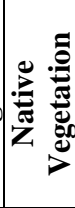 } & \multirow{2}{*}{ 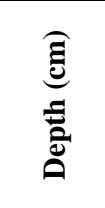 } & \multirow{2}{*}{$\begin{array}{l}\vec{B} \\
\dot{\Xi} \\
\frac{0}{0}\end{array}$} & \multirow{2}{*}{ 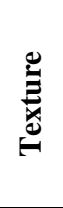 } & \multirow{2}{*}{ 苞 } & \multicolumn{3}{|c|}{ Consistence } & \multirow{2}{*}{ 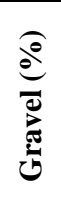 } & \multirow{2}{*}{ 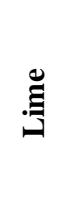 } & \multirow{2}{*}{ 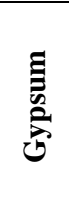 } & \multirow{2}{*}{ 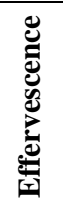 } & \multirow{2}{*}{ 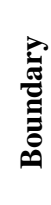 } \\
\hline & & & & & & & & & & $\vec{E}$ & $\frac{\vec{n}}{\tilde{b}}$ & 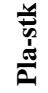 & & & & & \\
\hline \multirow{8}{*}{ 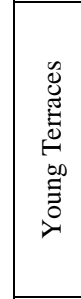 } & \multirow{2}{*}{1} & \multirow{2}{*}{$\begin{array}{l}\mathrm{G} \\
\mathrm{u}\end{array}$} & \multirow{2}{*}{$\mathrm{Nl}$} & \multirow{2}{*}{$\mathrm{Mg}$} & \multirow{2}{*}{$\mathrm{N}$} & $0-20$ & 10YR5/4 & $S$ & $\mathrm{~m}$ & $\mathrm{~S}$ & NS & $\mathrm{Np}$ & 2 & \multirow[b]{2}{*}{ - $^{-}$} & - & +++ & $\mathrm{CS}$ \\
\hline & & & & & & $20-100$ & \begin{tabular}{|l|} 
10YR6/6 \\
\end{tabular} & $\mathrm{S}$ & $\mathrm{m}$ & $\mathrm{S}$ & NS & $\mathrm{Np}$ & 10 & & - & +++ & - \\
\hline & \multirow{3}{*}{2} & \multirow{3}{*}{ U } & \multirow{3}{*}{$\mathrm{Nl}$} & & & $0-15$ & 10YR4/6 & SL & $\mathrm{m}$ & $\mathrm{S}$ & S.S & S.p & 5 & & v.f.S & +++ & $\mathrm{CW}$ \\
\hline & & & & $\mathrm{Cg}$ & $\mathrm{N}$ & $15-55$ & \begin{tabular}{|l|}
$10 \mathrm{YR} 7 / 2$ \\
\end{tabular} & SL & $\mathrm{m}$ & $\mathrm{S}$ & S.S & S.p & 15 & v.f.S & - & +++ & CS \\
\hline & & & & & & $55-70$ & 10YR7/2 & SL & $\mathrm{m}$ & Sh & S.S & S.p & 35 & & F.C & +++ & - \\
\hline & & & & & & $0-20$ & \begin{tabular}{|l} 
10YR6/6 \\
\end{tabular} & SL & $\mathrm{m}$ & S & S. & S.p & 5 & - & - & +++ & CS \\
\hline & 3 & $G$ & $\mathrm{Nl}$ & $\mathrm{Cg}$ & $\mathrm{N}$ & $20-40$ & $7 / 2$ & SL & $\mathrm{m}$ & $\mathrm{S}$ & $\bar{s}$ & S.p & 2 & C.S & - & +++ & CW \\
\hline & & & & & & $40-120$ & \begin{tabular}{|l|}
$10 \mathrm{YR} 7 / 2$ \\
\end{tabular} & SL & $\mathrm{m}$ & Sh & S. & S.p & 20 & F.S & - & +++ & - \\
\hline & & & & & & $0-20$ & \begin{tabular}{|l|} 
10YR6/6 \\
\end{tabular} & $\mathrm{S}$ & $\mathrm{m}$ & $\mathrm{S}$ & $\mathrm{N}$. & n.p & 13 & - & - & +++ & $\mathrm{CW}$ \\
\hline & 4 & Af & $\mathrm{Nl}$ & $\mathrm{Cg}$ & $\mathrm{N}$ & $20-50$ & \begin{tabular}{|l|}
$10 Y R 7 / 2$ \\
\end{tabular} & $S$ & $\mathrm{~m}$ & S & $\mathrm{N}$. & n.p & 20 & C.S & - & +++ & $\mathrm{CW}$ \\
\hline$\cong$ & & & & & & $50-100$ & \begin{tabular}{|l|}
$10 Y R 7 / 4$ \\
\end{tabular} & LS & $\mathrm{M}$ & Sh & $\mathrm{N}$. & n.p & 20 & F.S & - & +++ & ${ }_{-}^{-}$ \\
\hline 3 & & & & & & $0-10$ & 10YR7/6 & $\mathrm{S}$ & $\mathrm{M}$ & $\mathrm{S}$ & $\mathrm{N}$. & n.p & 1. & - & - & + & AS \\
\hline & 5 & Af & $\mathrm{Nl}$ & $\mathrm{Mg}$ & $\mathrm{N}$ & $10-35$ & 10YR6/6 & $\mathrm{S}$ & $\mathrm{M}$ & $\mathrm{S}$ & $\mathrm{N}$. & n.p & 20 & . & - & ++ & CS \\
\hline & & & & & & $35-70$ & 10YR6/6 & $\mathrm{S}$ & M & Sh & N.S & n.p & 15 & 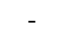 & -- & ++ & - \\
\hline & & & & & & $0-20$ & $6 / 6$ & SL & $\mathrm{M}$ & $\mathrm{S}$ & N.S & n.p & 15 & & - & +++ & GW \\
\hline & 6 & Af & $\mathrm{Nl}$ & Ms & $\mathrm{N}$ & $20-40$ & 10YR6/6 & S & $\mathrm{M}$ & $\mathrm{S}$ & $\mathrm{N}$ & n.p & 10 & $\mathrm{~S}$ & - & +++ & CW \\
\hline $\bar{z}$ & & & & & & $40-150$ & \begin{tabular}{|l|} 
10YR6/6 \\
\end{tabular} & LS & $\mathrm{M}$ & Sh & N.S & n.p & 25 &.$S$ & - & ++ & - \\
\hline & & & & & & $0-25$ & \begin{tabular}{|l|} 
10YR6/4 \\
\end{tabular} & SL & $\mathrm{M}$ & $\mathrm{S}$ & $\mathrm{M}$ & n.p & 5 & F.S- & - & +++ & $\mathrm{CW}$ \\
\hline & 7 & Af & $\mathrm{Nl}$ & & $\mathrm{N}$ & $25-70$ & 10YR6/4 & SL & M & Sh & M & $\mathrm{S}, \mathrm{p}$ & 30 & C.S & C.C & +++ & AW \\
\hline & & & & & & $70-120$ & 10YR6/4 & $\mathrm{SL}$ & $\mathrm{M}$ & Sh & $\mathrm{M}$ & n.p & 30 & F.S & - & +++ & - \\
\hline & & & & & & $0-20$ & \begin{tabular}{|l|}
$10 Y R 7 / 6$ \\
\end{tabular} & $\mathrm{~S}$ & $\mathrm{M}$ & 10 & $\mathrm{Ns}$ & $P$ & 10 & & - & ++ & CW \\
\hline & 8 & $\mathrm{U}$ & $\mathrm{Nl}$ & Dp & $\mathrm{N}$ & $20-40$ & 10YR6/6 & $S$ & $\mathrm{M}$ & $\mathrm{S}$ & $\mathrm{N}$ & $\mathrm{n} .1$ & 35 & y $\mathrm{C}$ & - & +++ & $\mathrm{CW}$ \\
\hline & & & & & & $40-120$ & 10YR4/6 & $\mathrm{LS}$ & $\mathrm{M}$ & $\mathrm{Sh}$ & $\mathrm{Ns}$ & n.p & 15 & .I.I. & v.f.S & ++ & - \\
\hline 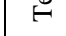 & & & & & & $0-15$ & 10YR5/6 & SCL & $\mathrm{M}$ & S & S.S & S.p & 15 & - & - & +++ & $\mathrm{CW}$ \\
\hline 可 & 9 & $\mathrm{U}$ & $\mathrm{Nl}$ & Dp & $\mathrm{N}$ & $15-35$ & 10YR5/4 & SCL & M & $\mathrm{S}$ & S. & S.p & 35 & C.S & C.S & +++ & $\mathrm{CW}$ \\
\hline & & & & & & $35-65$ & \begin{tabular}{|l} 
10YR6/5 \\
\end{tabular} & SL & M & Sh & S.S & s.p & 15 & - & - & +++ & - \\
\hline
\end{tabular}

Topography: AF Almost flat .GU:Gently Undulating :undulating Slope: NL: Nearly level .Coarse fragment :Mg; many different sizes of gravel. $\mathrm{Cg}$; Common different size of gravel .Ms;many stones\&gravel ;Dp;Desrt pavement Native Vegetation: N; None; Texture: S Sand SL Sandy Loam ; Structure : S.g Single grain ;m massive .Consistence: stiky ;NS;None sticky ;S.S; Slighty sticky; plastk; np; None plastic ;S.p; Slightly plastic.dry;s soft.sh slightly Effervescence: + week ++ moderate +++ strong Boundary: CS; Clear smoth. CW ;Clear Wavy. GW; Gradual wavy .AS; Abrupt smooth. AW Abrupt wavy. Lime; vfS; very few soft . FS,Few soft .CS,Common soft. Gypsum:, vfC very few Crystalline, FC,few Crystalline ,C.C ,Common crystalline.

Fayoum J. Agric. Res. \& Dev., Vol. 31, No.1, January, 2017 
Wahdan,M.E.M; et al.,

Table (2) Some physical properties of the studied area.

\begin{tabular}{|c|c|c|c|c|c|c|c|c|c|}
\hline \multirow{2}{*}{$\begin{array}{c}\text { Physiographic } \\
\text { Unit }\end{array}$} & \multirow{2}{*}{$\begin{array}{c}\text { Profile } \\
\text { No. }\end{array}$} & \multirow{2}{*}{$\begin{array}{l}\text { Depth } \\
(\mathbf{c m})\end{array}$} & \multicolumn{4}{|c|}{ Particle size distribution $(\%)$} & \multirow{2}{*}{$\underset{(\%)}{O . M}$} & \multirow{2}{*}{$\begin{array}{l}\text { Lime } \\
(\%)\end{array}$} & \multirow{2}{*}{$\begin{array}{l}\text { Gypsum } \\
(\%)\end{array}$} \\
\hline & & & Sand & Silt & Clay & $\begin{array}{c}\text { Textural } \\
\text { class }\end{array}$ & & & \\
\hline \multirow{8}{*}{$\begin{array}{c}\text { Young } \\
\text { Terraces }\end{array}$} & \multirow{2}{*}{1} & $0-20$ & 89.6 & 4.2 & 6.2 & $\mathrm{~S}$ & 0.08 & 7.9 & 0.8 \\
\hline & & $20-100$ & 90.4 & 5.3 & 4.3 & $\mathrm{~S}$ & 0.05 & 8.0 & 0.7 \\
\hline & \multirow{3}{*}{2} & $0-15$ & 63.0 & 19.1 & 17.9 & SL & 0.12 & 7.5 & 0.6 \\
\hline & & $15-55$ & 64.2 & 18.8 & 17.0 & SL & 0.07 & 8.0 & 0.5 \\
\hline & & $55-70$ & 65.0 & 16.5 & 18.5 & SL & 0.04 & 6.8 & 5.9 \\
\hline & \multirow{3}{*}{3} & $0-20$ & 63.6 & 17.5 & 18.9 & SL & 0.13 & 7.7 & 0.9 \\
\hline & & $20-40$ & 64.2 & 17.6 & 18.2 & SL & 0.06 & 12.8 & 0.6 \\
\hline & & $40-120$ & 79.9 & 9.2 & 10.9 & SL & 0.05 & 7.9 & 1.9 \\
\hline \multirow{6}{*}{ Wadis } & \multirow{3}{*}{4} & $0-20$ & 89.8 & 3.2 & 7.0 & $\mathrm{~S}$ & 0.09 & 7.3 & 0.6 \\
\hline & & $20-50$ & 86.5 & 8.5 & 5.0 & $\mathrm{~S}$ & 0.07 & 10.5 & 2.0 \\
\hline & & $50-100$ & 81.4 & 9.0 & 9.6 & LS & 0.03 & 7.4 & 1.2 \\
\hline & \multirow{3}{*}{5} & $0-10$ & 92.1 & 4.0 & 3.9 & $S$ & 0.11 & 1.7 & 0.6 \\
\hline & & $10-35$ & 89.1 & 7.0 & 3.9 & $S$ & 0.08 & 2.9 & 1.2 \\
\hline & & $35-70$ & 88.3 & 6.5 & 5.2 & $\mathrm{~S}$ & 0.04 & 0.8 & 0.6 \\
\hline \multirow{6}{*}{$\begin{array}{c}\text { Out wash } \\
\text { plain }\end{array}$} & \multirow{3}{*}{6} & $0-20$ & 81.3 & 6.7 & 12.0 & SL & 0.12 & 7.5 & 1.8 \\
\hline & & $20-40$ & 87.6 & 5.5 & 6.9 & $S$ & 0.07 & 7.7 & 0.2 \\
\hline & & $40-120$ & 86.5 & 6.3 & 7.2 & LS & 0.07 & 7.8 & 0.7 \\
\hline & \multirow{3}{*}{7} & $0-25$ & 79.6 & 10.0 & 10.4 & SL & 0.11 & 7.9 & 0.5 \\
\hline & & $25-70$ & 64.0 & 17.1 & 18.9 & SL & 0.08 & 17.6 & 15.4 \\
\hline & & $70-120$ & 63.0 & 17.6 & 19.4 & SL & 0.07 & 7.6 & 2.7 \\
\hline \multirow{6}{*}{$\begin{array}{c}\text { Old } \\
\text { Terraces }\end{array}$} & \multirow{3}{*}{8} & $0-20$ & 90.1 & 5.0 & 4.9 & $\mathrm{~S}$ & 0.06 & 2.9 & 0.6 \\
\hline & & $20-40$ & 89.8 & 4.3 & 5.9 & S & 0.03 & 2.9 & 1.0 \\
\hline & & $40-120$ & 80.3 & 11.3 & 8.4 & LS & 0.01 & 2.2 & 1.9 \\
\hline & \multirow{3}{*}{9} & $0-15$ & 58.3 & 16.2 & 25.5 & SCL & 0.05 & 12.8 & 1.5 \\
\hline & & $15-35$ & 54.8 & 22.2 & 23.0 & SCL & 0.03 & 17.0 & 3.7 \\
\hline & & $35-65$ & 58.5 & 22.5 & 19.0 & SL & 0,02 & 13.3 & 6.0 \\
\hline
\end{tabular}

S Sand. SL Sand Loam.LS Loam sand. SCL Sand Clay Loam. )

C)-Soils of Wadis: The wadi bottom soils are of little importance for the development of agriculture, being almost always represented by gravelly coarse sandy soils, further more they always occupy narrow strips of land. The bottom parts are characterized by stream beds. This physiographic unit is represented by profiles 4 and 5. Field observations in Table (1) clear that soils have the following characteristics ; almost flat. Topography, nearly level slope, common to many gravel of different size on the surface, nil native vegetation, moderately to deep soil depth. Soil dry color varied between light gray (10YR7/2) and brown yellowish (10YR6/6), sand to loamy sand textural classes, massive structure and coarse fregments ranged from 13to $20 \%$. Organic matter content varied between 0.03 and $0.11 \%$ and tends to decrease with depth. Total carbonate contents differ widely from 0.8 and $10.5 \%$ with an irregular distribution pattern with soil depth Accumulations of gypsum is week, where its contents differs from 0.6 and $2.0 \%$. Chemical properties presented in Table(3) show that soil .reaction $(\mathrm{pH})$ varied between 7.3 and 7.9

Fayoum J. Agric. Res. \& Dev., Vol. 31, No.1, January, 2017 
PEDOLOGICAL STUDIES ON SOME SOILS WEST.

which reveals neutral to moderately alkaline classes. ECe values changed from non-saline $(1.9 \mathrm{dS} / \mathrm{m})$ to moderately saline $(8.4 \mathrm{dS} / \mathrm{m})$ and tend to increase with depth in soils of profile 4 while opposite trend was found in soils of profile 5.The distribution pattern of soluble cations in the studied soils in general followed the descending order $\mathrm{Na}^{+}>\mathrm{Ca}^{2+}>\mathrm{Mg}^{2+}>\mathrm{K}^{+}$, while the soluble anions followed the order $\mathrm{Cl}^{-}$and/or $\mathrm{SO}^{-} 4>\mathrm{HCO}_{3}$. Values of sodium adsorption ration differed between 2.31 and 24.10. The soils of this unit were classified as Typic Torriorthents, sandy, mixed ,hyperthermic (profiles 4 and 5 ) D)-Soils of Outwash Plains: They are gravely sand soils and represented by profiles 6 and 7. The field observations which recorded in table (2) show almost flat topography, nearly level slope, with many stones and gravel on the surface, without native vegetation, with deep soil profiles. Soil dry colour varied from light yellowish brown (10YR6/4) to brownish yellow (10YR6/6). The soil textural class fluctuates between sandy to sandy loam, massive structure and gravel contents ranged from 5.0 to $30.0 \%$ (by volume). Data in Table (2) show that the organic matter contents are very low and range from 0.02 to $0.12 \% . \mathrm{CaCO}_{3}$ and gypsum contents vary from 7.5 to $17.6 \%$ and 0.2 to $15.4 \%$,respectively .The soils of profiles7 have calcic and gypsic horizons according to (USDA 2014). The chemical properties Table (4) show that soils reaction vary between neutral and moderately alkaline (7.3-8.0), soil salinity variy between non-saline to moderately saline where ECe values range between 1.6 and $13.2 \mathrm{dsm}^{-1}$. Soluble cations follow the order $\mathrm{Ca}^{2+}>\mathrm{Na}^{+}>$ $\mathrm{Mg}^{2+}>\mathrm{K}^{+}$, while soluble anions follow the order $\mathrm{Cl}^{-}>\mathrm{SO}^{=} 4>\mathrm{HCO}_{3}^{-}$. Values of sodium adsorption ratio are generally $<13$. According to USDA (2014),soils of outwash plains were classified as follows :Typic Torriorthents, sandy, mixed, hyperthermic (profile,6) Typic Calcigypsids, coarse loamy, mixed, hyperthermic (profile,7) .

Fayoum J. Agric. Res. \& Dev., Vol. 31, No.1, January, 2017 
Wahdan,M.E.M; et al.,

Table (3): Some chemical properties of the studied area.

\begin{tabular}{|c|c|c|c|c|c|c|c|c|c|c|c|c|c|}
\hline \multirow{2}{*}{ 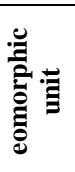 } & \multirow{2}{*}{ 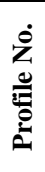 } & \multirow{2}{*}{ 言 } & \multirow{2}{*}{ 配 } & \multirow{2}{*}{ व } & \multicolumn{3}{|c|}{ Soluble Cations (me/L) } & \multicolumn{4}{|c|}{ Soluble Anions } & \multirow{2}{*}{ 俈 } & \multirow{2}{*}{ 商 } \\
\hline & & & & & $\mathrm{HCO}_{3}{ }^{-}$ & $C L^{-}$ & $\mathrm{SO4}^{2^{-}}$ & $\mathrm{Ca}^{2^{+}}$ & $\mathrm{Mg}^{2^{+}}$ & $\mathrm{Na}^{+}$ & $K^{+}$ & & \\
\hline \multirow{9}{*}{ 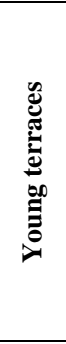 } & \multirow[t]{2}{*}{1} & $0-20$ & 7.4 & 2.1 & 2.8 & 4.0 & 15.7 & 10.6 & 3.4 & 7.5 & 1.0 & 2.83 & 2.84 \\
\hline & & $20-100$ & 8.3 & 0.9 & 4 & 2.0 & 3.0 & 1.8 & 1.1 & 5.7 & 0.4 & 4.71 & 5.38 \\
\hline & \multirow{4}{*}{2} & $0-15$ & 7.6 & 32.2 & 1.4 & 15.6 & 451.8 & 142.6 & 23.6 & 299.0 & 3.6 & 32.80 & 32.03 \\
\hline & & $15-55$ & 7.7 & 11.6 & 2.4 & 68.0 & 77.0 & 43.6 & 10.4 & 90.5 & 2.9 & 17.42 & 19.63 \\
\hline & & $55-70$ & 7.0 & 110.2 & 2 & 1272.0 & 466.8 & 378.3 & 166.1 & 1190.0 & 6.4 & 72.13 & 51.25 \\
\hline & & \multicolumn{12}{|c|}{ Rock } \\
\hline & \multirow{3}{*}{3} & $0-20$ & 7.2 & 30.0 & 1.5 & 222.5 & 157.0 & 101.5 & 30.5 & 245.0 & 4.0 & 30.16 & 30.18 \\
\hline & & $20-40$ & 7.3 & 26.0 & 1.1 & 56.0 & 255.0 & 7.8 & 112.3 & 189.0 & 3.0 & 24.39 & 25.77 \\
\hline & & $40-120$ & 7.3 & 65.4 & 1.5 & 700.0 & 248.5 & 123.7 & 106.9 & \begin{tabular}{|l|}
716.0 \\
\end{tabular} & 3.4 & 66.68 & 49.26 \\
\hline \multirow{7}{*}{ 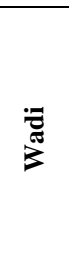 } & \multirow{3}{*}{4} & $0-20$ & 7.7 & 1.9 & 2 & 10.0 & 8.5 & \begin{tabular}{|l|}
8.2 \\
\end{tabular} & 1.7 & 10.5 & 0.1 & 4.70 & 5.36 \\
\hline & & $20-50$ & 7.5 & 2.8 & 2 & 20.0 & 7.6 & 6.2 & 2.4 & 20.6 & \begin{tabular}{|l|}
0.4 \\
\end{tabular} & 9.96 & 11.84 \\
\hline & & $50-100$ & 7.3 & 8.4 & 2.5 & $\begin{array}{l}51.8 \\
\end{array}$ & 42.8 & 23.6 & 6.9 & 65.0 & 1.6 & 16.66 & 18.90 \\
\hline & \multirow{4}{*}{5} & $0-10$ & 7.7 & 2.5 & 2.2 & 10.0 & 13.5 & \begin{tabular}{|l|}
12.6 \\
\end{tabular} & 2.8 & 9.2 & \begin{tabular}{|l|}
1.1 \\
\end{tabular} & 3.32 & 3.50 \\
\hline & & $10-35$ & 7.8 & 2.1 & 3.6 & 6.0 & 11.5 & 8.8 & 1.1 & 10.4 & 0.8 & 4.67 & 5.33 \\
\hline & & $35-70$ & 7.9 & 1.8 & 6 & 5.0 & 7.0 & 6.4 & 5.4 & 5.6 & \begin{tabular}{|l}
0.6 \\
\end{tabular} & 2.31 & 2.10 \\
\hline & & \multicolumn{12}{|c|}{ Rock } \\
\hline \multirow{6}{*}{ 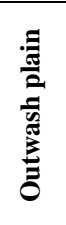 } & \multirow{3}{*}{6} & $0-20$ & 8.0 & 1.6 & 2 & 9.0 & 6.3 & 7.9 & 1.8 & 6.5 & \begin{tabular}{|l|}
1.1 \\
\end{tabular} & 2.95 & 3.00 \\
\hline & & $20-40$ & 7.8 & 9.6 & 1.8 & 53.0 & 63.3 & \begin{tabular}{|l|}
44.1 \\
\end{tabular} & 10.7 & 61.9 & 1.4 & 11.83 & 13.93 \\
\hline & & $40-120$ & 7.8 & 2.3 & 2.4 & 11.0 & 10.6 & 8.8 & 5.0 & 8.7 & 1.5 & 3.31 & 3.50 \\
\hline & \multirow{3}{*}{7} & $0-25$ & 7.9 & 1.9 & 2 & 3.0 & 15.0 & 7.8 & 1.4 & 9.8 & 1.0 & 4.57 & 5.20 \\
\hline & & $25-70$ & 7.3 & 10.7 & 4.4 & 36.0 & 92.2 & \begin{tabular}{|l|}
40.2 \\
\end{tabular} & 26.4 & 60.5 & 5.5 & 10.48 & 12.44 \\
\hline & & $70-120$ & 7.6 & 13.2 & 1.8 & 76.0 & 80.3 & \begin{tabular}{|l|}
54.8 \\
\end{tabular} & 25.3 & 73.0 & 5.0 & 11.54 & 13.61 \\
\hline \multirow{7}{*}{ 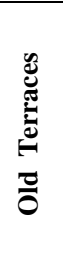 } & \multirow{3}{*}{8} & $0-22$ & 7.7 & 2.0 & 3.8 & 5.0 & 11.5 & 8.2 & 2.9 & 8.2 & 1.0 & 3.48 & 3.73 \\
\hline & & $20-40$ & 7.7 & 3.8 & 3 & 8.0 & 29.7 & \begin{tabular}{|l|}
12.6 \\
\end{tabular} & 5.8 & 21.4 & 0.9 & 7.06 & 8.38 \\
\hline & & $40-120$ & 7.7 & 2.9 & 3.2 & 10.0 & 17.2 & 9.5 & 1.7 & 18.5 & 0.7 & 7.82 & 9.31 \\
\hline & \multirow{4}{*}{9} & $0-15$ & 7.4 & 31.1 & 2.4 & 260.0 & 151.6 & \begin{tabular}{|l|}
78.3 \\
\end{tabular} & 20.5 & 312.0 & 3.2 & 44.39 & 39.10 \\
\hline & & $15-35$ & 7.4 & 44.6 & 1.6 & 440.0 & 147.0 & 157.6 & 47.0 & 380.0 & 4.0 & 37.57 & 35.13 \\
\hline & & $35-65$ & 7.4 & 40.0 & 2 & 300.0 & \begin{tabular}{|l|}
217.2 \\
\end{tabular} & \begin{tabular}{|l|}
188.0 \\
\end{tabular} & 22.6 & 306.0 & 2.6 & 29.82 & 29.93 \\
\hline & & \\
\hline
\end{tabular}

\section{Land Capability Classification}

Land capability classification of the studied area was carried out using the thematic layers of topography (t),wetness (w), soil depth (S2), texture (S1), $\mathrm{CaCO}_{3}$ (S3), gypsum (S4) and salinity and alkalinity (n) as shown in Table(4). The obtained data reveal that the most limiting factors in the soils of young and old terraces in the studied area are ,soil texture ,soil profile depth and salinity and alkalinity. The land capability in the outwash plain soils Is limited by soil texture, soil depth , $\mathrm{CaCO}_{3}$ and gypsum percentage, while in the wadies soils ,land capability is limited by soil texture ,soil depth, $\mathrm{CaCO}_{3}$ and salinity and alkalinity. The obtained data indicate that the classes of S3 and N dominate the studied area where .marginally suitable class S3 dominates the soils of old terraces (profiles 8 and 9). Outwash plain (profiles 6 and 7) and

Fayoum J. Agric. Res. \& Dev., Vol. 31, No.1, January, 2017 
PEDOLOGICAL STUDIES ON SOME SOILS WEST.

soils of young terraces (profile 3)have suitability index (Ci) that vary from 31 to50 indicating. Class N (not Suitable):

Table(4):Evaluation of the studied soils according to Sys \&Verheye(1978).

\begin{tabular}{|c|c|c|c|c|c|c|c|c|c|c|c|c|c|c|c|}
\hline \multirow{3}{*}{ 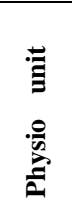 } & \multirow{3}{*}{ 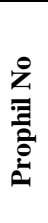 } & \multicolumn{2}{|c|}{$\begin{array}{c}\text { Topogra } \\
\text { Phy(t) }\end{array}$} & \multicolumn{2}{|c|}{$\begin{array}{l}\text { wetnees } \\
\text { (w) }\end{array}$} & \multicolumn{4}{|c|}{ Physical properties } & \multicolumn{4}{|c|}{$\begin{array}{c}\text { Suitability } \\
\text { Salinity }\end{array}$} & \multicolumn{2}{|c|}{$\begin{array}{c}\text { Suitability } \\
\text { class }\end{array}$} \\
\hline & & \multirow[b]{2}{*}{ C } & \multirow[b]{2}{*}{$\mathbf{P}$} & \multirow[b]{2}{*}{ C } & \multirow[b]{2}{*}{$\mathbf{P}$} & \multirow{2}{*}{ 珶 } & \multirow{2}{*}{ 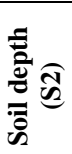 } & \multirow{2}{*}{$\underbrace{\infty}_{\tilde{E}} \widehat{\tilde{n}}$} & \multirow{2}{*}{ 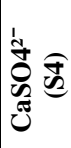 } & \multicolumn{2}{|c|}{ Alkalinity(n) } & \multicolumn{2}{|c|}{ Index } & \multirow[b]{2}{*}{ C } & \multirow[b]{2}{*}{$\mathbf{P}$} \\
\hline & & & & & & & & & & C & $\mathbf{P}$ & $\mathbf{C}$ & $\mathbf{P}$ & & \\
\hline \multirow{3}{*}{ 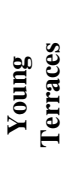 } & 1 & 95 & 100 & 100 & 100 & 30 & 90 & 95 & 90 & 100 & 100 & 22 & 23 & $\mathrm{~N} 2$ & $\mathrm{~N} 2$ \\
\hline & 2 & 90 & 100 & 100 & 100 & 65 & 75 & 95 & 100 & 45 & 100 & 19 & 46 & N1 & S3 \\
\hline & 3 & 95 & 100 & 100 & 100 & 65 & 90 & 95 & 100 & 58 & 100 & 31 & 56 & S3 & S2 \\
\hline \multirow{2}{*}{ 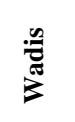 } & 4 & 95 & 100 & 100 & 100 & 38 & 90 & 95 & 100 & 58 & 100 & 18 & 32 & N1 & S3 \\
\hline & 5 & 95 & 100 & 100 & 100 & 25 & 75 & 95 & 90 & 100 & 100 & 15 & 16 & $\mathrm{~N} 2$ & $\mathrm{~N} 2$ \\
\hline \multirow{2}{*}{ 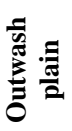 } & 6 & 95 & 100 & 100 & 100 & 51 & 90 & 95 & 90 & 100 & 100 & 37 & 39 & S3 & S3 \\
\hline & 7 & 95 & 100 & 100 & 100 & 65 & 90 & 100 & 100 & 90 & 100 & 50 & 59 & S3 & S2 \\
\hline \multirow{2}{*}{ 흘 } & 8 & 90 & 100 & 100 & 100 & 41 & 90 & 95 & 100 & 100 & 100 & 32 & 35 & S3 & S3 \\
\hline & 9 & 90 & 100 & 100 & 100 & 83 & 75 & 100 & 100 & 58 & 100 & 32 & 62 & S3 & S2 \\
\hline
\end{tabular}

C:Current suitability P:Potential suitability S1:Highly suitable75-100 S2:Moderately suitable50-75 S3:Marginallysuitable25-50 N:ot suitable<25.

This class dominates the soils of Wadies (profiles 4 and 5 ) and young terraces soils (profiles 1and 2).The suitability index $(\mathrm{Ci})$ in these soils below $25 \%$ as a results of very severe soil texture and salinity and alkalinity limitations .Further land improvements are required to correct or to reduce the severity of limitation exiting in the studied area such as leveling the soils surface, leaching of soil salinity and reclamation of alkalinity existing in the soils by using gypsum as a soil amendment and continuous application of organic manure to improve soil-phyic-chemical properties and fertility status.

Application of the potential capability index (Pi) for the studied soil profiles is presented in Tale(4). The result reveal that the studied soil profiles are placed between $(\mathrm{S} 2)$ and $(\mathrm{N})$ classes as follows: soils of class (S2) (moderately suitable): The soils of class $\mathrm{S} 2$ are represented by profile 3 (young terraces ). The soils of this class are effected by soil texture and soil profile depth limitation.

Soils of class S3 (marginally suitable ): The soils of this class are represented by profile 2 (young terraces ), profile 4 (Wadi),profile 6(Outwash plain) and profiles 8 and 9 Old terraces ).These soils have moderate limitations

Fayoum J. Agric. Res. \& Dev., Vol. 31, No.1, January, 2017 
which are different in their kind and degree. In general, the recognized dominate limitation are soil texture, soil profile depth and $\mathrm{CaCO}_{3}$ content .

Soils of class N(Not suitable) : The soils of this class are represented by two profiles which represent the soils of young terraces (profile 1 ) and wadi (profile 5). These soils are effected by sever limitation as, soil texture ,soil profile depth ,CaCO3 and gypsum content.

\section{REFERENCES}

Abo El Ezz.,M.S., L(2000)" Landforms of Egypt",281p,the AM. Univ . Cairo, PESS, Cario, Egypt

EL-Osta,M.M.S (2006). Evaluation and management of ground water in EastEl-Oweinat area, Western Desert, Egypt. Ph.D. Thesis, Fac. of Sci, Minufiya Univ., Egypt .

Dobos E,Norman B,Bruee W,Luca M ,Chris J and Enka M(2002)The use of DEM and satellite images for regional scale soil database. $17^{\text {th }}$ Word Congress of Soil Science (WCSS) .14-21August 2002 Bangkok, Thailand

FAO/SF: 16/UAR(1963), High Dam soil survey, United Arab Republic Volume II, the Reconnaissance Soil Survey, United Nations Development Program (Special Fund).

FAO (1985), "Guidelines: Land evaluation for irrigated agriculture, FAO Soils Bulletin No.55,Rome,Italy

FAO (2006),"Guidelines for soil description "fourth Edition, FAO, Rome, ISBN 92-5-105521-10.

Meteorological authority (2014). "The normal for Egypt up to 2014. Ministry of Civil aviation, Cairo, Egypt. Meteorological Res. Bull., 32:55-65.

Munsell Soil Color Chats (2010) Munsell soil color charts Baltimore ,MarylandS (U.S.A)

Ozsoy G,A (2007) :Characterization, classification and agricultural usage of vertisols developed on eogene aged calcareous marl parent materials J.Biol . Environ.Sci.1 (1): 5-10.Cited from soil mapping approach in GIS. Using Landsat Satellite imagery and DEM data.

Shehata, A.M.A.(2003). Hydrochemicals Studied of ground water in the area Btween El-Oweint and Tushka (East Oweinat ).PhD Thesis,Fac of Sci, Al-Azhar., Univ., Cairo-Egypt.

(Sys. C. and Verheye W (1978), An attempt to the evaluation of physical land characteristics for irrigation according to the FAO framework

Fayoum J. Agric. Res. \& Dev., Vol. 31, No.1, January, 2017 
PEDOLOGICAL STUDIES ON SOME SOILS WEST

for land evaluation. Int. Train. Center for Post-Grad., Soil.Sci,.,Ghent, Belgium.

Sys, Sys, C, Van Ranst, E and Debavey J. (1991), An evaluation. Part I and S2,Ghent Univ., Ghent Belgium. of physical land characteristics for irrigation according to the FAO framework for land evaluation. Int. Train. Center for Post- Grad., Soil.Sci,.,Ghent, Belgium.

Thorweihe ,U. (1990). Nubian aquifer system in :The geology of Egypt (ed.R.Said) .Balkem A.A. a puplishers, Brookfield,pp.(611-661).

USDA (2004). Soil survey laboratory methods manual "Soil survey investugation report No.42Version4.0 November 2004

USDA (2014), Key of soil taxonomy. Prepared by Agronomy Department Cornell Uni.Ithaco, New York, USA.

Zinck,J.A.and C.R., Valenzuela ,1990. Soil geographic database:structure and application examples. Itcj.,3:270.

Fayoum J. Agric. Res. \& Dev., Vol. 31, No.1, January, 2017 


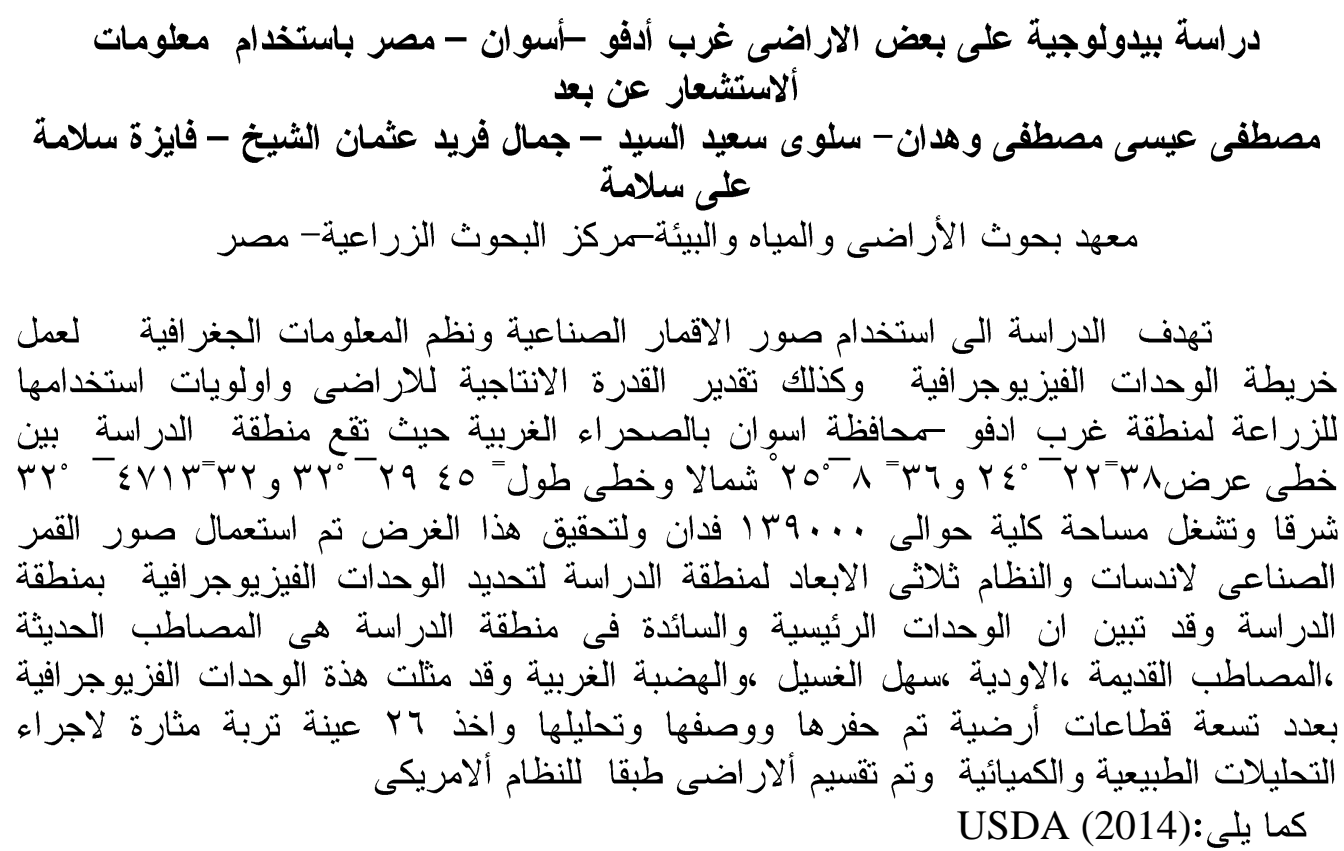

A)-Soils of Old Terraces: Typic Torriorthents, sandy, mixed, hyperthermic.(Profile8).Gypsic Haplosalids coarse loamy, mixed hyperthermic. (profile9)

B)-Soils of the Young terraces: a) Typic Torripsamments siliceaus, hyperthermic (profil,1)-b) Gypsic Haplosalides coarse loamy, mixed, hyperthermic(profile,2)-c). Typic Haplosalides, coarse loamy, mixed, hyperthermic. profiles 2 and3.

C)-Soils of Wadis: Typic Torriorthents, sandy, mixed, hyperthermic(profiles 4 and 5 )

D)-Soils of Outwash Plains:. TypicTorriorthents, sandy ,mixed ,hyperthermic (profile,6) Typic Calcigypsids, coarse loamy,mixed,hyperthermic (profile,7).

تبين الاراضى تحت الدراسة انها ذات مستوى ملائمة بين غير صالحة (N) وحدية الصناحية

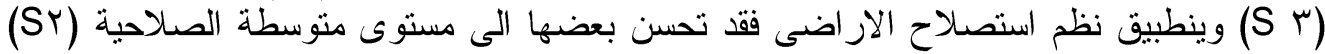

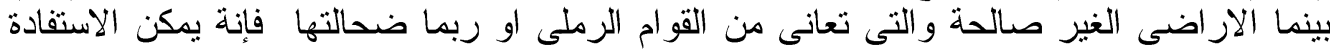

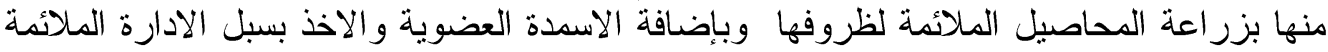
وتطبيق نظم الرى الاكثر ملائمة و وغير ذلكة للك.

Fayoum J. Agric. Res. \& Dev., Vol. 31, No.1, January, 2017 